\title{
Teaching global climate change
}

\author{
Alan H. McGowan \\ Environmental Studies Program, The New School, New York, USA; mcgowana@newschool.edu
}

Received 26 November 2012; revised 28 December 2012; accepted 10 January 2013

\begin{abstract}
Although there is strong consensus among scientists that global climate change is real and dangerous, and there is increasing belief of this among the general public, there still remains a significant gap between scientific opinion and that of the public. The academic environmental community, therefore, has a clear opportunity and responsibility to teach the facts of global climate change, particularly to non-environmental majors, those people who are the voters of the future. The article presents several ideas along these lines, and calls for a revitalized effort to teach climate change to undergraduate students.
\end{abstract}

Keywords: Climate Change; Environment; Education; Undergraduate; General Education

\section{INTRODUCTION}

The data are clear. There is an overwhelming consensus among scientists that global climate change is real and happening now [1]. The data are also clear that though 67 percent of Americans think there is solid evidence that the climate is warming, only 42 percent say that it is due to human activities [2]. Further, only 45 percent feel that the scientific community agrees that it is due to human activities; 43 percent say that they do not [2].

Other polls give similar data [3]. Though representing an encouraging increase in people who believe in climate change, it still is quite obvious that there is a gap between the opinion of the experts and the opinions of the general public [4]. Among environmentalists in academia, therefore, there is a rather large obligation to educate as many students as we can, particularly those who are not environmental majors, but rather those who will graduate to be doctors, lawyers, and other professionals; members of the general public who will play large roles in shaping public opinion.

The university in which I teach has a dedicated Environmental Studies Program, a school of design that has devoted itself to the concept of sustainability - a required freshman course is Sustainable Energy Systems-a graduate program called Environmental Policy and Sustainable Management, and many other courses throughout the curriculum of many of its divisions. History of the Environment, The Environment and Literature, and courses of a like nature, are scattered throughout various programs.

It is too early to tell what, if any, change in public opinion will ensue after the advent of Sandy, the hurricane that so devastated the East Coast of the United States in October 2012. Though we must be extremely careful about what we claim, it is nonetheless true that these storms are at least exacerbated by global warming, as shown by Dr. James Hansen and others [5]. The article by Hansen et al. was picked up by many, if not most, major news outlets, including PBS, Business Week, CNN, and others [6,7].

Sandy, as Katrina did before it, laid bare the large ethical issues embodied in climate change. Why are the most devastated often the ones least able to afford it? How can we protect poor communities, which often exist in the low lying areas most vulnerable to storm surges? Why should taxpayers subsidize the insurance for people who live in the flood plain? These issues are often the ones that grab the students the most.

The following three courses which I teach, described below, are meant only as examples for what can be done. There are many fruitful ways in which these ideas can be presented. I would hope that we could start a dialogue as to the many ways that we can carry out our responsibilities.

\section{THE COURSES}

There are three: Environment and Society, a course designed by my colleague P. Timon McPhearson, Assistant Professor in the Environmental Studies Program; Energy and Sustainability, designed by me along with other colleagues in the Interdisciplinary Science Department; and Renewable Energy, which I designed. After briefly describing the courses, with their differences and similarities, I will discuss some of the issues that arise.

\subsection{Environment and Society}

A gateway course to the Environmental Studies Pro- 
gram and required for majors, the course has been taught for the last three years to great acclaim. It has been taught by two full time professors and one postdoctoral fellow, and each time it has filled to capacity. Although the work load is not light, students come into the course with enthusiasm, and leave with even more, though a bit chastened by the difficulties they see looming ahead. The course deals with the following topics:

- An introduction to basic principles of ecology (the department teaches an introductory course Principles of Ecology)

- Ecosystem Services

- Population

- Sustainability Science

- Fossil Fuels

- Renewable Energy: solar in all its manifestations, tidal, and geothermal

- Nuclear Power

- Global Climate Change

- The Urban Environment

- Environmental Justice

- Social Activism and Sustainability

It is a survey course, only capable of skimming the surface. Students do get a sense of the basic issues, however, and many leave with a desire to learn more. It is a seminar course, which means that students are responsible for a large part of the discussion. One student for each day is assigned the responsibility to lead a portion of the discussion for that day, focusing on the reading and other information they have found themselves. (One of the very important skills students can learn in college, in addition to writing, is presentation skills.) Most students do extremely well in this aspect of the course, and like it.

The readings come from a text book [8], a book of nature writing [9], and a number of scholarly and popular articles relevant to the course; [10-15], for example. On one day, students are required to bring in one scholarly and one popular article of their choosing and present their findings in class. Students are exposed, though briefly, to current scholarship in the many fields of environmental science.

\subsection{Energy and Sustainability}

This is a course originally designed by the Department of Natural Sciences and Mathematics, but taken over by me five years ago and substantially changed. It is a required course for the Interdisciplinary Science major, and is intended to be a gateway course for it.

Energy is a key factor in our lives, and it fuels the economy. Many of the unacceptable income and social disparities in the world can be traced to energy inequality, both as a cause and effect of income inequality. It is also highly political; the course starts with a sampling of readings that demonstrate the intensely political and military nature of energy [16-19].

In order to give the students some understanding of the epistemology of science, and also because energy plays such a key role in climate change, the class starts by reading and discussing Spencer Weart's book on the discovery of global warming [20]. The book carefully examines the many false starts that are part of any scientific investigation, and also points out the political issues that contributed to funding or the lack thereof for the science. Students sometimes find the many tangents that the science has taken over the years difficult to follow, but understand its importance once they have finished it. One of the strongest critics of the book, also one of the best students I have ever had, stood up in class about the middle of the term and stated she had changed her view of the book since she had just been at a party and felt very comfortable defending the importance of climate change because she had read the book. It is important that students know what we know in science, but also what are the limits of that knowledge, how we discovered it, and what is our level of uncertainty.

The course then turns to its core, the physics and chemistry of energy. Topics covered include the laws of thermodynamics, particularly conservation of energy, and the topic of energy; Carnot cycle engines and the impossibility of $100 \%$ efficient heat engines; and chemical energy and where it comes from. The students do a personal energy inventory, where they document every use of energy in a 24 hour period, including cooking, riding the subway to work, lighting in their study and living spaces, food that they eat, and so forth. They are usually amazed at the amount of energy they use. The exercise makes the point of the centrality of energy in their lives.

We examine various sources of energy other than from fossil fuels, solar, geothermal, tidal, and nuclear. To no surprise, the most controversial source is nuclear. Many students come in with an anti-nuclear opinion, some very strongly so. Because I think nuclear power is going to play an important part in the debate over how to combat climate change, I spend some time on nuclear power, its origins in the Manhattan Project, and the many myths that have surrounded it since its inception. (I also teach a course on The Science and Politics of the Atom Bomb, which deals with both the history of the science and also the thorny question of whether the bomb shortened the war [21-23].)

Finally, we deal with the economics, not primarily the cost of renewables versus fossil fuels, but rather the fraught issue of how much we should be willing to pay for avoiding a cost fifty years, say, in the future. The groundbreaking Stern Review [24] attempts to answer this question by assuming a given cost in the future, then discounting back from that to the present to determine an amount that we should be willing to pay now. Although it 
has been widely criticized [25], it is not so much the details as the importance of the attempt that makes it useful. Students find it difficult to grasp, but most feel the struggle is worth it.

\subsection{Renewable Energy}

The third one I teach in this suite of courses is Renewable Energy, an intermediate level course, which requires Energy and Sustainability as a prerequisite, or permission of the instructor. Although it uses a textbook for some basic information [26], it is fundamentally a project based course, one the entire class works on as a group. The project is to determine what it would take to have a totally carbon free energy economy in the United States by 2050. Succeeding classes take the results of the previous class and check and refine them.

Each student selects a particular energy source he or she wants to study; the choice is collaborative, so as to avoid overlap. Providing efficiencies is considered an energy "source;" some students choose efficiencies in transportation, for example, while others tackle buildings. In addition to the cost and availability of the power source, students take into account the amount of land necessary. It provided a rude awakening for many; the amount of land required, for example, was not a problem many had thought about.

Again, nuclear power proved the most controversial, with some students taking a strong anti-nuclear stance. In addition to some attention the safety and health costs of various technologies, we examined their availability, cost, and land mass requirements. A detailed examination of health and safety concerns will have to be considered in another, yet more advanced, course.

The United States currently uses 98 quadrillion BTUs of energy per year, which is the base amount we start from. That is, either by conservation or sources of energy other than fossil fuels, we have to come to this magic figure. Although there is a study coming out of Stanford University that states we can be carbon free by 2030 [27], and another book that discusses Germany's transition to renewable energy $[28,29]$ with the implication that the United States can do the same thing, the students found it difficult to come to that number without serious conservation, and without the use of nuclear energy. They learned that it is not going to be an easy transition.

For most, it was an eye-opening experience. To quote one: "This is so hard! I thought we could just go to solar and that would be it. I had no idea it was going to be this difficult." Having students do their own calculations, rather than just being told about it, made it real for them.

\section{CONCLUSION}

There are several points to be made here. The most important one is that many students are genuinely inter- ested in these topics, even those that are afraid of science and mathematics - several students have said they never imagined they would be in a science class - and they can end up not only doing well in the course, but developing a more complete understanding of the issues involved. These students are graduating in a few short years and taking jobs of all kinds; it is our responsibility to develop courses of this kind, even in schools which do not have environmental studies programs. There is plenty of material available which can help, from textbooks to numerous articles from well-respected sources that can be part of a course. We do not want to propagandize, but our purpose should be to ensure that as many students as we can reach are armed with facts and understanding.

Almost as important is having students do projects and calculations on their own, even when they have to be helped through those calculations. It is an unfortunate fact of life that many students come into college woefully unprepared in both mathematics and science, but doing even a minimal amount of number crunching on their own gives them a sense of ownership.

This activity also provides a place on campus where climate change issues are discussed, so that even students who don't take the courses often have friends who do, and it becomes a part of student discussions. I have been asked many times for interviews in the student newspaper and radio station, and even to appear in other classes, all because I am known to teach these courses. In many schools, including mine, there are school clubs that are devoted to sustainability, often coming out of these classes. It is all part of a general education program in which all academic environmentalists should be involved.

There is one problem, and that is class size. Although we know that the kind of collaborative learning in which one can engage in small classes is much better for retention than lecture style classes [30-32], we do need to reach large audiences. The good news is that there is increasing information that online classes can achieve some of the same results [33,34]. Although it is beyond the scope of this article to discuss it, a next step would be to explore how online courses can be effective in spreading the message of global climate change. Perhaps the next MOOC (massively open online course) will be this. We must do more than we are doing now.

\section{REFERENCES}

[1] Solomon, S., Qin, D., Manning, M., Chen, Z., Marquis, M., Averyt, K.B., Tignor, M. and Miller, H.L., Eds. (2007) Contribution of working group I to the fourth assessment report of the intergovernmental panel on climate change, Intergovernmental Panel on Climate Change.

[2] Gerken, J. (2012) Pew climate change poll reveals that less than half of americans make anthropogenic connection. 
[3] Yale Project on Climate Change Communication (2012) Extreme weather and climate change in the American mind. Yale School of Forestry \& Environmental Studies, New Haven.

[4] Leiserowitz, A.A., Smith, N. and Marlon, J.R. (2010) Americans' knowledge of climate change. Yale University Project on Climate Change Communication, New Haven.

[5] Hansen, J., Sato, M. and Ruedy, R. (2012) Perception of climate change. Proceedings of the National Academy of Sciences.

[6] Anonymous (2012) Recent heat waves caused by global warming, Hansen says. http://www.businessweek.com/news/2012-08-05/recent-h eat-waves-caused-by-global-warming-hansen-says

[7] Srinivasan, U.T. (2012) James Hansen: Extreme heat events connected to climate change. http://www.pbs.org/newshour/rundown/2012/08/james-ha nsen-extreme-heat-events-connected-to-climate-change.ht $\underline{\mathrm{ml}}$

[8] Wright, R.T. and Boorse, D. (2011) Environmental science: Toward a sustainable future. Benjamin Cummings, Boston.

[9] McKibben, B. and Gore, A. (2008) American earth: Environmental writing since Thoreau. Penguin Putnam, New York.

[10] Bryant, B.I. (1995) Environmental justice: Issues, policies, and solutions. Island Press, Washington DC.

[11] Bullard, R.D. (1994) Unequal protection: Environmental justice and communities of color. Sierra Club Books, San Francisco.

[12] Cutter, S.L. (1995) Race, class and environmental justice. Progress in Human Geography, 19, 111-122. doi:10.1177/030913259501900111

[13] Elliott, K. (2008) Biofuels and the food price crisis: A survey of the issues. Center for Global Development.

[14] Kates, R.W., Parris, T.M. and Leiserowitz, A.A. (2005) What is sustainable development goals, indicators, values, and practice. Environment, 47, 9-21.

[15] Kates, R. and Dasgupta, P. (2007) African poverty: A grand challenge for sustainability science. Proceedings of the National Academy of Sciences, 194, 16747-16750. doi:10.1073/pnas.0708566104

[16] Holbrooke, R. (2008) The next president: Mastering a daunting agenda. Foreign Affairs, 87.

[17] Klare, M.T. (2001) Wealth, resources and power, in resource wars. Metropolitan Books, New York.

[18] Klare, M.T. (2004) The Carter Doctine goes global. The

\section{Progressive, 68.}

[19] Liska, A.J. and Perrin, R.K. (2010) Securing foreign oil: A case for including military operations in the climate change impact of fuels, in environment. Taylor \& Francis, Philadelphia.

[20] Weart, S.R. (2003) The discovery of global warming. New histories of science, technology, and medicine. Harvard University Press, Cambridge.

[21] Rhodes, R. (1986) The making of the atomic bomb. Simon \& Schuster, New York.

[22] Hasegawa, T. (2005) Racing the enemy: Stalin, Truman, and the surrender of Japan. Belknap Press of Harvard University Press, Cambridge.

[23] Frank, R.B. (1999) Downfall: The end of the Imperial Japanese Empire. Random House, New York.

[24] Stern, L.N. (2005) Stern review: The economics of climate change executive summary. Office of Climate Change, London.

[25] Yohe, G.W. and Tol, R.S.J. (2007) The stern review: Implications for climate change. Environment, 49, 36-42. doi:10.3200/ENVT.49.2.36-43

[26] Risinin, R.A. and Kraushaar, J.P. (2006) Energy and the environment. 2nd Edition, John Wiley \& Sons, New York.

[27] Jacobson, M.Z. and Delucchi, M.A. (2009) A path to sustainable energy by 2030. Scientific American, 58-65. doi:10.1038/scientificamerican1109-58

[28] Fran, O. (2012) Clean break: The story of Germany's energy transformation and what American can learn from it. Kindle.

[29] Osha (2012) Clean break: The story of Germany's energy transformation and what American can learn from it. Kindle.

[30] Bruffee, K.A. (1999) Collaborative learning: Higher education, interdependence, and the authority of knowledge. 2nd Edition, John Hopkins University Press, Baltimore.

[31] Bransford, J. (2000) How people learn: Brain, mind, experience, and school. National Academy Press, Washington DC.

[32] National Research Council (US), Committee on How People Learn a Targeted Report for Teachers, Donovan, S. and Bransford, J. (2005) How students learn: Mathematics in the classroom. National Academies Press, Washington DC.

[33] Gokhale, A.A. (1995) Collaborative learning enhances critical thinking. Journal of Technology Education, 7, 6.

[34] Stacey, E. (1999) Collaborative learning in an online environment. Journal of Distance Education, 14, 14-33 